\title{
KEPUASAN KONSUMEN: FAKTOR-FAKTOR YANG MEMPENGARUHI
}

\author{
Marlina Kurnia ${ }^{1}$, Suwiknyo ${ }^{2}$, \\ Universitas Muhammadiyah Magelang
}

\begin{abstract}
This article investigates the influence of brand awareness, perceived quality, brand association, brand loyalty, tangible, reliability, responsiveness, assurance, empathy customer satisfaction. The population is the customer in BPR Meru Sankara, the sample is taken with convinience with slovin method. Using sample 96 and tested using SPSS software. The results of this study show Perception Quality, Reliability, Responsiveness and Empatimiliki influence and significant to Customer Satisfaction. Thus the proposed hypothesis proves true. As for Brand Awareness, Brand Associations, Brand Loyalty, Physical Evidence and Guarantee no effect on Customer Satisfaction so that the hypothesis proposed is not proven. Further research is expected to add variable motivation and corporate culture in researching customer satisfaction.
\end{abstract}

Keywords $\quad$ : Brand Quality, Sistem Quality, customer satisfaction

Correspondence to : marlinakurnia@ummgl.ac.id

\begin{abstract}
ABSTRAK
Penelitian ini ingin mengetahui faktor yang memepengaruhi kepuasan konsumen, seperti brand awareness, perceived quality, brand association, brand loyalty, tangible, reliability, responsiveness, assurance, empathy. Populasi dalam penelitian ini adalah nasabah BPR Meru Sankara, denagn teknik pengambilan sample dengan accidental sampling. Sampel yang digunakan adalah 96 dan diolah menggunakan SPSS software.Hasil dari penelitian ini menjelaskan hubungan antara Perception Quality, Reliability, Responsiveness dan Empatimemiliki pengaruh pada kepuasan pelanggan. Sedangkan hubungan antara Brand Awareness, Brand Associations, Brand Loyalty, Physical Evidence dan Guarantee tidak memiliki pengaruh pada Customer Satisfaction. Penelitian selanjutnya diharapkan dapat menambah variabel yang diteliti yaitu motivasi dan kepuasan pelanggan.
\end{abstract}

Kata kunci $\quad$ : Brand Quality, Sistem Quality, customer satisfaction

Korespondensi $\quad$ : marlinakurnia@ummgl.ac.id

\section{PENDAHULUAN / INTRODUCTION}

Industri sektor perbankan syariah memang sedang berkembang pesat. Ini terlihat dari peningkatan aset dari posisi Desember 2015 sebesar Rp. 296,26 triliun menjadi sebesar Rp. 356,50 triliun atau meningkat
20,33\% di Desember 2016 (www.ojk.go.id). Industri syariah bisa bersaing dan meningkatkan pangsa pasar dengan menjaga dan memperoleh keunggulan kompetitif atas pesaingnya. Hal ini bertujuan mempertahankan kepuasan konsumen sebagai 
faktor kunci dalam rangka untuk mempertahankan hidup dalam persaingan yang kompetitif. Nasabah yang merasa puas atas jasa yang diperoleh maka akan melakukan proses pembelian ulang atau kembali menggunakan jasa tersebut. Konsumen yang puas juga akan memberikan referensi yang baik atas jasa tersebut kepada orang lain.

Harapan konsumen dan janji dari perusahaan kepada konsumen dapat dijembatani oleh adanya merek. Dengan demikian dapat diketahui ikatan emosional antara konsumen dengan penghasil jasa melalui merek. Ekuitas merek sendiri mempunyai empat dimensi utama yang berkaitan langsung dengan konsumen, yaitu : kesadaran merek (brand awareness), persepsi kualitas (perceived quality), asosiasi merek (brand association) dan loyalitas merek (brand loyalty).

Konsumen yang telah tertarik dan melakukan pemilihan produk jasa yang akan digunakan selanjutnya akan menilai bagaimana kualitas pelayanan yang diterima. Sehingga dapat diketahui tingkat kepuasan konsumen. Menurut Kotler yang dikutip oleh Tjiptono (1996) menyatakan bahwa kualitas harus dimulai dari kebutuhan pelangan dan berakhir pada persepsi pelanggan. Pihak yang menilai suatu jasa itu berkualitas atau tidak adalah konsumen karena merekalah yang mengkonsumsi jasa perusahaan. Untuk itu perusahaan agar dapat bersaing harus menyediakan jasa yang mempunyai kualitas pelayanan yang tinggi dan berkesinambungan.

Apabila layanan yang
diterima/dirasakan sesuai dengan harapan maka kualitas layanan dipersepsikan baik dan memuaskan. Dan apabila pelayanan melebihi apa yang diharapkan, maka dapat dikatakan pelayanan yang ideal. Baik tidaknya layanan tergantung pada kemampuan penyedia layanan dalam memenuhi harapan pelanggannya secara konsisten.
Penelitian yang dilakukan oleh Lely Ana Ferawati Ekaningsih dan Maria Ulfa (2015) yang melakukan penelitian mengenai pengaruh kualitas produk dan kualitas pelayanan terhadap kepuasan nasabah Tabungan Haji Arafah : studi kasus Bank Muamalat Indonesia KCP Genteng Kab Banyuwangi. Hasilnya kedua variabel bebas tersebut memiliki pengaruh signifikan dan dominan terhadap kepuasan nasabah. Artikel ini bertujuan untuk membuktikan pengaruh brand awareness, perceived quality, brand association, brand loyalty, tangible, reliability, responsiveness, assurance, empaty) terhadap kepuasan nasabah

$$
\text { Kotler (2002:42), Kepuasan }
$$

pelanggan adalah perasaaan senang atau kecewa seseorang yang muncul setelah membandingkan antara persepsi/kesannya terhadap kinerja (hasil) dan harapanharapannya. Kepuasan bisa diartikan sebagai upaya pemenuhan kebutuhan atau membuat sesuatu memadai.Menurut Zeithaml dan Bitner (2000:75) definisikepuasan adalah: respon atau tanggapan konsumen mengenai pemenuhankebutuhan. Kepuasan merupakan penilaian mengenai ciri ataukeistimewaan produk atau jasa, atau produk itu sendiri, yang menyediakantingkat kesenangan konsumen berkaitan dengan pemenuhan kebutuhankonsumsi konsumen.

Menurut

Lovelock (2007)

menjelaskan bahwa kepuasan adalah keadaan emosional, reaksi pasca pembelian mereka dapat berupa kemarahan, ketidakpuasan, kejengkelan, kegembiraan atau kesenangan.Tidak mengherankan bahwa perusahaan telah menjadi terobsesi dengan kepuasan pelanggan, mengingat hubungannya yang langsung dengan kesetiaan pelanggan, pangsa pasar dan keuntungan. Kepuasan pelanggan/nasabah total tidak mungkin terjadi, akan tetapi ada cara untuk meminimalisir ketidakpuasan pelanggan dengan beberapa strategi. 
Berdasarkan penelitian yang dilakukan oleh Barwise pada tahun 1993 (Rangkuti, 2002) pada saat itu banyak praktisi periklanan menggunakan istilah "brand equity" (ekuitas merek). Sejak saat itu sampai sekarang terdapat tiga teori yang banyak dipakai mengenai istilah brand equity, yaitu brand equity yang dikaitkan dengan nilai uang (financial value), brand equity yang dikaitkan dengan perluasan merek (brand extension) dan brand equity yang diukur dari perspektif pelanggan.

Kesadaran merek (brand awareness) menunjukkan kesanggupan seorang calon pembeli untuk mengenali atau mengingat kembali bahwa suatu merek merupakan bagian dari kategori produk tertentu.Kesadaran merek adalah merupakan informasi mengenai tingkat kemapuan konsumen untuk mengenal dan mengingat keberadaan suatu produk (Umar, 2000:425). Peran brand awareness dalam keseluruhan brand equity tergantung dari sejauh mana tingkatan kesadaran yang dicapai oleh suatu merek.

Asosiasi merek tidak hanya eksis, namun juga memiliki suatu tingkat kekuatan. Keterkaitan pada suatu merek akan lebih kuat apabila dilandasi pada banyak pengalaman atau penampakan untuk mengkomunikasikannya. Berbagai asosiasi yang diingat konsumen dapat dirangkai sehingga membentuk citra tentang merek atau brand image di dalam benak konsumen. Mencerminkan persepsi pelanggan terhadap keseluruhankualitas/keunggulan suatu produk atau jasa layanan berkenaan dengan maksud yang diharapkan.Kesan kualitas sebuah merek memberikan alasan yang penting untuk membeli. Hal ini mempengaruhi merek-merek mana yang harus dipertimbangkan dan selanjutnya mempengaruhi merek apa yang akan dipilih. Keuntungan kedua adalah diferensiasi. Artinya, suatu karakteristik penting dari merek adalah posisinya dalam dimensi kesan kualitas. Keuntungan ketiga adalah harga optimum. Kuntungan ketiga ini memberikan pilihan-pilihan di dalam menetapkan harga optimum (premium price). Keuntungan keempat ini memiliki arti penting bagi para distributor, pengecer serta berbagai saluran distribusi lainnya, karena hal itu sangat membantu perluasan distribusi. Kuntungan kelima adalah perluasan merek. Kesan kualitas dapat dieksploitasi dengan cara mengenalkan berbagai perluasan merek, yaitu dengan menggunakan merek tertentu untuk masuk kedalam kategori produk baru.

Brand loyalty (loyalitas merek) merupakan suatu ukuran keterkaitan pelanggan kepada sebuah merek (Durianto, Sugiarto, Sitinjak, 2001:126 dalam Arvianti, 2004 Loyalitas merek merupakan inti dari brand equity yang menjadi gagasan sentral dalam pemasaran, karena hal ini merupakan satu ukuran keterkaitan seorang pelanggan pada sebuah merek. Apabila loyalitas merek meningkat, maka kerentanan kelompok pelanggan dari serangan kompetitor dapat dikurangi. Hal ini merupakan suatu indikator dari brand equity yang berkaitan dengan perolehan laba di masa yang akan datang karena loyalitas merek secara langsung dapat diartikan sebagai penjualan di masa depan.

Kotler yang dikutip oleh Tjiptono (1996) menyatakan bahwa kualitas harus dimulai dari kebutuhan pelanggan dan berakhir pada persepsi pelanggan. Pihak yang menilai suatu jasa itu berkualitas atau tidak adalah pelanggan karena merekalah yang mengkonsumsi jasa perusahaan. Untuk itu suatu perusahaan jasa yang ingin tetap unggul bersaing harus dapat menyediakan jasa yang mempunyai kualitas tinggi secara berkesinambungan. Kualitas pelayanan berpusat pada suatu kenyataan yang ditentukan oleh pelanggan. Interaksi strategi pelayanan, sistem pelayanan dan sumber daya manusia serta pelanggan akan sangat 
menentukan keberhasilan dari manajemen perusahaan.

Menurut Wyckof (dalam Lovelock, 1998) dalam buku Zulian Yamit (2004:47), Kualitas pelayanan adalah tingkat keunggulan yang diharapkan dan pengendalian atas tingkat keunggulan tersebut untuk memenuhi keinginan pelanggan.Archana Subramaniam, Abdullah Al Mamun, P. Yukthamarani Permarupan \& Noor Raihani Binti Zainol (2014), Effects of Brand Loyalty, Image and Quality on Brand Equity: A Study among Bank Islam Consumers in Kelantan, Malaysia. Hasil temuan penelitian ini menunjukkan pengaruh yang signifikan positif loyalitas merek dan citra merek pada ekuitas merek dari Bank Islam. Di antara tiga faktor dicatat dalam model regresi, loyalitas merek memiliki efek yang jauh lebih tinggi dari ekuitas merek dari citra merek dan persepsi kualitas. Loyalitas konsumen memainkan peran penting dalam kelangsungan hidup jangka panjang dari industri apapun. Di sektor perbankan, di mana layanan yang hampir sama, sangat sulit untuk mendapatkan pelanggan setia.

Lely Ana Ferawati Ekaningsih Maria ulfa (2015), Pengaruh Kualitas Produk Dan Kualitas Pelayanan Terhadap Kepuasan Nasabah Tabungan Haji Arafah Pada Bank Muamalat Indonesia Kcp Genteng Kabupaten Banyuwangi. Hasilnya terdapat pengaruh secara simultan antara variabel kualitas produk dan kualitas pelayanan terhadap kepuasan nasabah tabungan haji pada Bank Muamalat Indonesia KCP Genteng Kabupaten Banyuwangi. Variabel kualitas produk memiliki nilai koefisien regresi sebesar 0,330 dengan signifikansi sebesar 0,132 dan variabel kualitas pelayanan memiliki koefisien regresi sebesar 0,208 dengan signiifikansi sebesar 0,171 . Dengan demikian, antara kedua variabel bebas, variabel kualitas produk (X1) memiliki pengaruh paling dominan terhadap kepuasan pelanggan.
Teuku Aliansyah, et al (2012), Pengaruh Dimensi Kualitas Pelayanan Terhadap KepuasanNasabah Bank Aceh Syariah Cabang Banda Aceh. Hasilnya Dimensi kualitas pelayanan yang terdiri dari tangibles, empathy, realibility, responsiveness dan assurance secara parsial dan simultan berpengaruh positif terhadap kepuasan nasabah.Arianis Chan (2010), Pengaruh Ekuitas Merk Terhadap Proses Keputusan Pembelian Konsumen: Studi Kasus Bank Muamalat Indonesia Cabang Bandung. Hasilnya keputusan pembelian konsumen untuk menjadi nasabah Bank Muamalat tinggi, hal ini dinilai dari ekuitas merk (brand awareness),(brand association), (perceived quality) dan (brand layalty).

Ariyanti dan Nurmalasari (2015), Pengaruh Kualitas Layanan Terhadap Kepuasan Nasabah Menggunakan Metode Regresi Linier Studi Kasus PT. Bank Central Asia Tbk Cabang Kalimalang. Hasilnya adalah bahwa kualitas layanan internet banking KlikBCA dimensi yang terdiri dari efisiensi, pemenuhan, kehandalan dan privasi berpengaruh secara signifikan terhadap kepuasan pelanggan. Hasil tes menunjukkan bahwa kepuasan pelanggan 60,9 \% dapat dijelaskan oleh variabel layanan KlikBCA berkualitas dengan dimensi efisiensi, pemenuhan, kehandalan dan privasi, yang berarti bahwa 39,1 \% dipengaruhi oleh variabel lain yang tidak dalam lingkup penelitian penulis.

Kinerja pelayanan adalah hasil kerja yang dicapai oleh pegawai dalam melaksanakan tugas sesuai dengan tanggung jawabnya yang diukur berdasarkan indikator bukti fisik (tangible), keandalan (reliability), daya tanggap (responsiveness), jaminan (assurance) dan empati (emphaty).Dari teori tersebut dapat diambil kesimpulan bahwa brand equity dan kualitas pelayanan berpengaruh positif terhadap kepuasan 
nasabah/pelanggan. Sehingga hipotesis yang

diturunkan adalah:

\begin{tabular}{|l|c|l|}
\hline H1 & $:$ & Kesadaran merek (brand awareness) berpengaruh terhadap kepuasan nasabah \\
\hline H2 & $:$ & Persepsi kualitas (perceived quality)berpengaruh terhadap kepuasan nasabah \\
\hline H3 & $:$ & Asosiasi merek (brand association)berpengaruhterhadap kepuasan nasabah \\
\hline H4 & $:$ & Loyalitas merek (brand loyalty) berpengaruh terhadap kepuasan nasabah \\
\hline H5 & $:$ & Bukti fisik (tangible)berpengaruhterhadap kepuasan nasabah \\
\hline H6 & $:$ & Keandalan (reliability)berpengaruhterhadap kepuasan nasabah \\
\hline H7 & $:$ & Daya tanggap (responsiveness)berpengaruhterhadap kepuasan nasabah \\
\hline H8 & $:$ & Jaminan (assurance)berpengaruhterhadap kepuasan nasabah \\
\hline H9 & $:$ & Empati (empathy) berpengaruhterhadap kepuasan nasabah \\
\hline
\end{tabular}

\section{METODE PENELITIAN / METHODS}

\section{Populasi dan Sampel}

Populasi dalam penelitian ini adalah seluruh nasabah simpanan dan atau pembiayaan per tanggal 30 April 2017 yang berjumlah 2.167 nasabah (Data BPRS Meru Sankara). Penentuan jumlah sampel dalam penelitian ini menggunakan rumus Slovin (Sekaran 1992). Sehingga mendapatkan jumlah sampel 96 orang. Teknik pengambilan sampel dengan metode accidental sampling.Sampel penelitian faktor-faktor yang mempengaruhi kepuasan nasabah studi kasus pada kantor pusat BPR Syariah Meru Sankara adalah 96 responden. Terdiri dari responden yang berjenis kelamin pria sebanyak 44 responden $(45,83 \%)$, responden wanita 52 responden (54,17\%),berarti bahwa sebaran responden dari penelitian ini lebih didominasi oleh responden wanita.

\section{Operasional variabel}

1. Brand EquityMenurut Durianto, Sugiarto dan Budiman (2004) pengukuran ekuitas merek telah dikembangkan oleh Aaker menjadi model Brand Equity Ten. Pengukuran-pengukuran dikelompokkan dalam lima katagori. Empat katagori yang pertama mewakili persepsi konsumen tentang suatu merek melalui empat dimensi merek, yaitu loyalitas, pesepsi kualitas, asosiasi dan kesadaran loyalty, perceived quality, association and awareness). Katagori kelima meliputi pengukuran dua jenis perilaku pasar (market behaviour) yang mewakili informasi yang diperoleh berdasarkan pasar dan bukan langsung dari konsumen.

2. Kualitas PelayananAdalah kinerja faktor pelayanan yang dirasakan responden/nasabah. Dimensi kualitas pelayanan terdiri dari variabel:

a. Bukti fisik (Tangible), kemampuan dalam menunjukkan eksistensi kepada pihak eksternal, indikatornya kenyamanan ruangan pelayanan, karyawan yang berpenampilan rapi dan kelengkapan peralatan yang digunakan.

b. Keandalan (Reliability), kemampuan untuk memberikan pelayanan sesuai yang dijanjikan secara akurat, indikatornya ketepatan bank dalam memenuhi janji, kemampuan dalam memecahkan masalah nasabah dan pelayanan tepat dan akurat.

c. Daya tanggap (Responsiveness), membantu dan memberikan pelayanan yang cepat dan tepat kepada nasabah, dengan penyampaian informasi yang jelas, indikatornya 
kecepatan dalam pelayanan, kemampuan karyawan dalam menenangkan nasabah dan cara karyawan menyambut nasabah.

d. Jaminan (Assurance), pengetahuan, kesopanan dan kemampuan para pegawai untuk menumbuhkan rasa percaya para nasabah kepada perusahaan, indikatornya kepercayaan nasabah kepada karyawan, sikap karyawan dalam memberikan pelayanan dan pengetahuan karyawan terhadap produk bank.

e. Empati (Empathy), memberikan perhatian yang tulus dan bersifat individual atau pribadi kepada nasabah dengan berupaya memahami keinginan nasabah, indikatornya perhatian pribadi karyawan kepada nasabah, kepekaan karyawan untuk mengetahui minat nasabah dan sikap karyawan memenuhi kebutuhan khusus nasabah.

3. Kepuasan Nasabah

Kepuasan nasabah adalah persepsi responden/nasabah setelah menggunakan jasa dari perusahaan. Indikatornya yaitu nasabah merasa puas atas kinerja jasa dan merekomendasikan jasa tersebut kepada orang lain.

\section{HASIL DAN PEMBAHASAN / RESULTS AND DISCUSSION}

Model analisis data yang digunakan dalam penelitian ini adalah analisis regresi berganda (multiple regression analysis). Analisis regresi berganda digunakan untuk menganalisis pengaruh variabel bebas kesadaran merek (brand awareness) (X1), persepsi kualitas (perceived quality) (X2), asosiasi merek (brand association) (X3), loyalitas merek (brand loyalty) (X4), bukti fisik (tangibles) (X5), keandalan (reliability) (X6), daya tanggap (responsivenes) (X7), jaminan (assurance) (X8)danempati (empathy) (X9) terhadap variabel terikat yaitu kepuasan nasabah (Y). Pengujian hipotesis secara parsial maupun simultan dilakukan dengan menggunakan pengolahan data SPSS (Statistical Program for Social Sciences) dengan versi 16.0.

\section{Uji Validitas, Uji Reliabilitas dan Uji Normalitas}

Instrumen yang valid adalah alat ukur yang digunakan untuk mendapatkan data yang valid dan dapat digunakan mengukur apa yang hendak diukur. Dengan tingkat signifikasi 5\% dan jumlah n sebanyak 96 responden, maka didapat $r_{\text {tabel }}$ adalah 0,1689 . Hasil penelitian ini menyebutkan bahwa 29 butir pernyataan yang diajukan dalam kuisioner memiliki nilai validitas $>0,1689$ sehingga 29 butir pernyataan semua valid.

Instrumen yang reliabel berarti instrumen tersebut bila digunakan beberapa kali untuk mengukur objek yang sama akan menghasilkan data yang sama. Tingkat reliabilitas ini dapat dilihat pada nilai cronbach's alpha. Reliabilitas suatu variabel dikatakan baik jika memiliki nilai cronbach's alpha $>0,6$

Nilai $F_{\text {hitung }}$ menunjukkan nilai sebesar 19,429 (signifikansi $\mathrm{F}=0,000$ ). Sedang $\mathrm{F}_{\text {tabel }}$ dihitung pada tabel $\mathrm{F}$, dengan $\alpha=0,05$ $(5 \%)$ dan $\mathrm{df}_{1}(\mathrm{~N} 1)=9(\mathrm{k}-1), \mathrm{df}_{2}(\mathrm{~N} 2)=86(\mathrm{~N}-$ $\mathrm{k}$ ), didapat $\mathrm{F}_{\text {tabelyaitu }} 1,99$. Jadi $\mathrm{F}_{\text {hitung }}>\mathrm{F}_{\text {tabel }}$ $(19,429>1,99)$ atau Sig $\mathrm{F}<5 \%(0,000<0,05)$. Artinya bahwa secara bersama-sama variabel kesadaran merek (brand awareness) (X1), persepsi kualitas (perceived quality) (X2), asosiasi merek (brand association) (X3), loyalitas merek (brand loyalty) (X4), bukti fisik (tangibles) (X5), keandalan (reliability) (X6), daya tanggap (responsivenes) (X7), jaminan (assurance) (X8)danempati (empathy) (X9) berpengaruh secara positif dan signifikan terhadap kepuasan nasabah (Y). Maka H0 Ditolak. 


\section{Uji Hipotesis}

Hasil uji hipotesis dengan menggunakan software spss dapat dilihat melalui Variabel Kesadaran Merek (X1) nilai $t_{\text {hitung }}$ sebesar 1,433 dengan signifikansi sebesar $\quad 0,156$. Karena $\quad \mathrm{t}_{\text {hitung }}<\mathrm{t}_{\text {tabel }}$ $(1,433<1,985)$ atau sig $\mathrm{t}>5 \%(0,156>0,05)$, maka dapat disimpulkan persepsi responden tentang BPR Syariah Meru Sankara untuk variabel Kesadaran Merek (X1) secara parsial tidak mempengaruhi variabel Kepuasan Nasabah (Y) bila variabel bebas lain tetap nilainya. Maka hipotesis 1 tidak terdukung.Secara teoritik,kesadaran merek merupakan informasi mengenai tingkat kemampuan konsumen mengenal dan mengingat keberadaan suatu produk (Umar, 2000:425). Sehingga seorang nasabah yang mampu mengingat dan menyebutkan suatu merek pasti sudah pernah menggunakan atau menerima informasi berkaitan produk tersebut. Jadi seharusnya kesadaran merek dapat berpengaruh signifikan. Akan tetapi berdasar melihat item pernyataan dalam kuesioner, kaitannya dengan nama dan logo dari BPR Syariah Meru Sankara dibandingkan dengan merek-merek lainnya dimungkinkan para responden belum menerima informasi atau promosi yang dapat menyajikan simbol dan trademark. Juga dapat diasumsikan bahwa para responden lebih mengutamakan sektor pelayanan.

Pengaruh Persepsi Kualitas terhadap Kepuasan Nasabah.Variabel Persepsi Kualitas (X2) nilai thitung sebesar 2,674 dengan signifikansi sebesar 0,009 . Karena $t_{\text {hitung }}>t_{\text {tabel }}$ $(2,674>1,985)$ atau sig $\mathrm{t}<5 \%(0,009<0,05)$ maka dapat disimpulkan persepsi responden tentang BPR Syariah Meru Sankara untuk variabel Persepsi Kualitas (X2) secara parsial mempengaruhisecara positif dan signifikan terhadap variabel Kepuasan Nasabah (Y) bila variabel bebas lain tetap nilainya. Maka hipotesis terdukung. Didukung teori menurut Freddy Rangkuti 2002, nilai dari persepsi kualitas diantaranya yaitu alasan untuk membeli, diferensiasi/posisi, harga optimum, minat saluran distribusi dan perluasan merek. Hal ini mendukung hasil dari penelitian ini. Hasil penelitian ini mengandung makna bahwa, berdasarkan pernyataan dalam kuesioner, responden sudah merasa kualitas pelayanan dari pembukuan, sistem operasional maupun keamananmenjadikan mereka puas dalam menggunakan jasa BPR Syariah Meru Sankara.

Pengaruh Asosiasi Merek terhadap Kepuasan Nasabah. Variabel Asosiasi Merek (X3) nilai thitung sebesar -0,461 dengan signifikansi sebesar 0,646 . Karena $t_{\text {hitung }}<\mathrm{t}_{\text {tabel }}$ $(-0,461<-1,985)$ atau sig $\mathrm{t}>5 \%(0,646>0,05)$ maka dapat disimpulkan persepsi responden tentang BPR Syariah Meru Sankara untuk variabel Asosiasi Merek (X3) secara parsial tidak mempengaruhi variabel Kepuasan Nasabah (Y) bila variabel bebas lain tetap nilainya. Maka Hipotesis tidak terdukung. Hal ini menjadikan variabel ini tidak layak dijadikan alat variabel penentu. Hal ini seharusnya tidak terjadi karena berdasarkan teoritis Freddy Rangkuti 2002, salah satun nilai asosiasi merek yaitu menciptakan sikap/perasaan positif. Ketidak konsistenan parameter ini dikarenakan: belum banyak masyarakat umum yang mengetahui perbedaan antara bank umum dan BPR serta perbedaan layanan antara konvensional dan syariah. Dengan tingkat pengetahuan yang bervariasi dan dominan pengetahuan responden yang masih minim menjadikan jawaban yang juga tidak konsisten.

Pengaruh Loyalitas Merek terhadap Kepuasan Nasabah. Variabel Loyalitas Merek (X4) nilai thitung sebesar 1,635 dengan signifikansi sebesar 0,106 . Karena $t_{\text {hitung }}<\mathrm{t}_{\text {tabel }}$ $(1,635<1,985)$ atau sig $\mathrm{t}>5 \%(0,106>0,05)$ maka dapat disimpulkan persepsi responden tentang BPR Syariah Meru Sankara untuk variabel Loyalitas Merek (X4) secara parsial tidak mempengaruhi variabel Kepuasan 
Nasabah (Y) bila variabel bebas lain tetap nilainya. Maka Hipotesis tidak terdukung. Variabel ini tidak layak dijadikan variabel penentu, Loyalitas merek yang paling tinggi akan menjadikan nasabah komitmen untuk terus menggunakan suatu produk dan juga sebagai identitas siapa mereka jika menggunkan merek tersebut. Dengan loyalitas merek ini maka akan terjadi interaksi terus menerus antara konsumen dengan produsen sehingga akan menjadikan perbaikan terus menerus berkaitan sehingga nasabah akan merasa puas. Akan tetapi bagi nasabah yang yang belum dalam tingkatan komitmen, maka akan mudah untuk beralih ke merek yang lain walaupun mereka harus menanggung biaya peralihan. Hal ini bisa dikarenakan perubahan harga, pelayanan lebih dari produsen lain maupun karena nasabah yang memang senang berpindah-pindah.

Pengaruh Bukti Fisik terhadap Kepuasan Nasabah. Variabel Bukti Fisik (X5) nilai $t_{\text {hitung }}$ sebesar 0,019 dengan signifikansi sebesar $\quad 0,985$. Karena $\quad \mathrm{t}_{\text {hitung }}<\mathrm{t}_{\text {tabel }}$ $(0,019<1,985)$ atau sig $\mathrm{t}>5 \%(0,985>0,05)$ maka dapat disimpulkan persepsi responden tentang BPR Syariah Meru Sankara untuk variabel Bukti Fisik (X5) secara parsial tidak mempengaruhi variabel Kepuasan Nasabah (Y) bila variabel bebas lain tetap nilainya. Maka H0 terdukung.Hal ini tidak sejalan dengan teori dari Parasuraman, et.all (Tjiptono 1996) bahwa bukti fisik merupakan indikator yang paling kongkrit, wujud dari segala fasilitas yang secara nyata dapat terlihat. Ketidakkonsistenan ini kemungkinan dikarenakan dari seluruh karyawan yang ada mempunyai tingkat pelayanan dan penampilan fisik yang berbeda, selain itu juga tingkatan kehidupan ekonomi, pendidikan, pekerjaan maupun sosial dari responden yang juga bervariatif maka akan menjadikan persepsi yang berbeda pula.

Pengaruh Keandalan terhadap Kepuasan Nasabah. Variabel Keandalan (X6) nilai $t_{\text {hitung }}$ sebesar -2,221 dengan signifikansi sebesar 0,029 . Karena $t_{\text {hitung }}>t_{\text {tabel }}(-2,221>-$ $1,985)$ atau sig $\mathrm{t}<5 \%(0,029<0,05)$ maka dapat disimpulkan persepsi responden tentang BPR Syariah Meru Sankara untuk variabel Keandalan (X6) secara parsial mempengaruhisecara negatif dan signifikan terhadap variabel Kepuasan Nasabah (Y) bila variabel bebas lain tetap nilainya. Maka H0 tidak terdukung.Keandalan merupakan kemapuan memberikan pelayanan yang dijanjikan dengan segera dan memuaskan. Kenyataan hasil penelitian ini dapat dijelaskan bahwa, apabila pihak perusahaan atau produsen tidak mampu memenuhi kebutuhan nasabah dengan cepat dan tidak mengecewakan, maka nasabah akan merasa kecewa dan akan berpindah ke pihak lain.

Pengaruh Daya Tanggap terhadap Kepuasan Nasabah. Variabel Daya Tanggap (X7) nilai thitung sebesar 2,316 dengan signifikansi sebesar 0,023 . Karena $\mathrm{t}_{\text {hitung }}>\mathrm{t}_{\text {tabel }}(2,316>1,985)$ atau sig $\mathrm{t}<5 \%$ $(0,023<0,05)$ maka dapat disimpulkan persepsi responden tentang BPR Syariah Meru Sankara untuk variabel Daya Tanggap (X7) secara parsial mempengaruhisecara positif dan signifikan terhadap variabel Kepuasan Nasabah (Y) bila variabel bebas lain tetap nilainya. Maka hipotesis diterima. Variabel ini layak dijadikan alat pengujian. Hal ini didukung teori dari Parasuramann, et.all (Tjiptono 1996), bahwa daya tanggap merupakan suatu akibat dari akal dan pikiran yang ditunjukkan kepada pelanggan. Pelanggan atau nasabah yang merasa diperhatikan, disapa dan diberikan pelayanan dengan cepat akan merasa puas. Selain itu daya tanggap juga bisa dijadikan tolok ukur seberapa lama nasabah harus menungu untuk bisa menyelesaikan kebutuhannya.

Pengaruh Jaminan terhadap Kepuasan Nasabah. Variabel Jaminan (X8) nilai thitung sebesar 0,452 dengan signifikansi sebesar 0,652 . Karena $t_{\text {hitung }}<t_{\text {tabel }}(0,452<1,985)$ atau 
sig $\mathrm{t}>5 \% \quad(0,652>0,05)$ maka dapat disimpulkan persepsi responden tentang BPR Syariah Meru Sankara untuk variabel Jaminan (X8) secara parsial tidak mempengaruhi variabel Kepuasan Nasabah (Y) bila variabel bebas lain tetap nilainya. Maka Hipotesis tidak terdukung. Variabel ini berdasarkan pernyataan dalam kuesioner menjelaskan kaitannya faktor kejujuran pelayanan, kesopanan dan kemampuan dalam menjelaskan informasi produk dengan jelas dan tuntas. Seharusnya variabel ini layak digunakan sebagai acuan karena dalam sektor jasa, faktor-faktor tersebut sangatlah berdampak terhadap interaksi langsung dengan nasabah yang akan menjadikan nasabah apakah memahami informasi yang diberikan sesuai apa adanya atau tidak.

Pengaruh Empati terhadap Kepuasan Nasabah. Variabel Empati (X9) nilai thitung sebesar 3,952 dengan signifikansi sebesar 0,000 . Karena $t_{\text {hitung }}>t_{\text {tabel }}(3,952>1,985)$ atau sig $\mathrm{t}<5 \% \quad(0,000<0,05)$ maka dapat disimpulkan persepsi responden tentang BPR Syariah Meru Sankara untuk variabel Empati (X9) secara parsial mempengaruhi secara positif dan signifikan terhadap variabel Kepuasan Nasabah (Y) bila variabel bebas lain tetap nilainya. Maka hipotesis terdukung. Variabel ini sangat layak dijadikan sebagai alat estimasi. Menurut Parasuraman, et.all (Tjiptono 1996), empati dilaksanakan secara pribadi atau individu terhadap pelanggan dengan menempatkan dirinya pada situasi pelanggan. Dalam praktik pelayanan, mempererat hubungan dengan nasabah yang masih eksis merupakan salah satu cara untuk mewujudkan kepuasan nasabah. Dengan hal ini akan menjadikan hubungan jangka panjang, memberikan tanggapan yang lebih cepat, memungkinkan perusahaan menyesuaikan variasi kebutuhan bagi para nasabah dan juga timbal balik nasabah akan dengan cepat dirasakan perusahaan.
Hal ini juga menjelaskan hasil jawaban atas pernyataan kuesioner yang diberikan kepada responden, dapat disimpulkan bahwa semua variabel independen yang terdiri dari dimensi brand equity dan kualitas pelayananyang secara kesatuan/bersama-sama mempengaruhi secara positif dan signifikan terhadap variabel dependen Kepuasan Nasabah.

Berdasarkan hipotesis secara parsial, diketahui bahwa variabel Empati (X9) memiliki pengaruh yang paling dominan terhadap Kepuasan Nasabah (Y) pada nasabah Kantor Pusat BPR Syariah Meru Sankara Magelang. Berdasarkan analisis yang disajikan pada Tabel 14 terlihat nilai koefisien regresi untuk masing-masing variabel, Variabel Empati memiliki nilai koefisien regresi sebesar 0,260 dengan signifikansi sebesar 0,000 .

Hasil analisis data menggunakan analisis regresi linier berganda dapat diketahui bahwa variabel Persepsi Kualitas, Keandalan, Daya Tanggap dan Empati berpengaruh signifikan terhadap Tingkat Kepuasan Nasabah. Dengan adanya kualitas sumberdaya manusia yang baik dari karyawan, akan menambah kepuasan dari nasabah.Sedangkan untuk variabel Kesadaran Merek, Asosiasi Merek, Loyalitas Merek, Bukti Fisik dan Jaminan tidak berpengaruh signifikan terhadap Tingkat Kepuasan Nasabah.

Variabel Empati merupakan variabel yang paling dominan dalam menjelaskan/mempengaruhi Kepuasan Nasabah, hal ini mendukung penelitian sebelumnya yang dilakukan oleh Puspa Zeni Isdiyanti (2016) yang melakukan penelitian pada nasabah PT BCA, Tbk Kantor Cabang Pembantu Temanggung. Berdasarkan hasil yang didapatkan secara simultan kesembilan variabel independen berpengaruh signifikan positif terhadap variabel dependen. Dengan $F_{\text {hitung }}>F_{\text {tabel }}(19,429>1,99)$ atau Sig $F<5 \%$ $(0,000<0,05)$. 
Berdasar hasil ini Pimpinan Bank dapat mencari strategi lain dengan menggunakan faktor-faktor diluar elemen tersebut agar dapat memberikan dan meningkatkan persentase

\section{KESIMPULAN, SARAN, DAN KETERBATASAN PENELITIAN}

Berdasarkan hasil analisa penelitian mengenai faktor-faktor yang mempengaruhi Kepuasan Nasabah, studi kasus pada nasabah BPR Syariah Meru Sankara Magelang maka dapat simpulkan Dari hasil persamaan regresi menunjukkan bahwa variabel Persepsi Kualitas, Keandalan, Daya Tanggap dan Empatimempunyai pengaruh dan signifikan terhadap Kepuasan Nasabah. Dengan demikian hipotesis yang diajukan terbukti kebenarannya. Sedangkan untuk variabel Kesadaran Merek, Asosiasi Merek, Loyalitas Merek, Bukti Fisik dan Jaminan tidak berpengaruh terhadap Kepuasan Nasabah sehingga hipotesis yang diajukan tidak terbukti.

Penelitian ini hanya meneliti pengaruh dimensi brand equity yaitu kesadaran merek, persepsi kualitas, asosiasi merek dan loyalitas merek serta dimensi kualitas pelayanan yang terdiri dari bukti fisik, keandalan, daya tanggap, jaminan dan empati. Masih ada faktor-faktor lain yang mempengaruhi kepuasan nasabah seperti kualitas produk, transaksi dan relationship.Peneliti juga dapat menambah jumlah perusahaan dalam penelitiannya serta menambah ataupun mengkombinasikan variabel penelitian yang digunakan.

\section{DAFTAR PUSTAKA / BIBLIOGRAPHY}

Aaker, David A. 1997. Manajemen Ekuitas Merek. (Aris)

Aliansyah,Teuku.et al. 2012. Pengaruh Dimensi Kualitas Pelayanan Terhadap Kepuasan Nasabah Bank AcehSyariah CabangBanda Aceh. Jurnal Manajemen. Volume 1. (1). 32-39. pengaruh terciptanya kepuasan nasabah terhadap BPR Syariah Meru Sankara Magelang.

Arianis Chan. 2010. Pengaruh Ekuitas Merk Terhadap Proses Keputusan Pembelian Konsumen : Studi Kasus Bank Muamalat Indonesia Cabang Bandung.Jurnal Administrasi Bisnis. Volume 6. (1). 43-58.

Ariyanti dan Nurmalasari. 2015. Pengaruh Kualitas Layanan Terhadap Kepuasan Nasabah Menggunakan Metode Regresi Linier Studi Kasus PT. Bank Central Asia Tbk Cabang Kalimalang. Jurnal Pilar Mandiri. Volume XI. (2). 112-125.

Azizah, Euis. 2013. Kualitas Layanan Terhadap Kepuasan Nasabah. Jurnal Studia Akuntansi dan Bisnis. Volume 1. (2). 165-176.

Bitner and Parasuraman et al,. 2005, Relationship Between Online Service Quality And Customer Satisfaction. A Study in Internet Banking. Department of Business Administration and Social Sciences Division of Industrial Marketing and ecommerce. Sweden: Lulea University of Technology.

Durianto, Darmadi, dkk. 2004. Strategi Menaklukkan Pasar melalui Riset Ekuitas dan Perilaku Merek.Jakarta:Penerbit PT. Gramedia Pustaka Utama.

Ekaningsih, Lely Ana Ferawati dan Maria ulfa. 2015. Pengaruh Kualitas Produk Dan Kualitas Pelayanan Terhadap Kepuasan Nasabah TabunganHaji Arafah Pada Bank Muamalat Indonesia KCP Genteng Kabupaten Banyuwangi. Jurnal Hukum Islam dan Bisnis. Volume 1. (1).

Kotler, Philip dan A.B Susanto. 2001. Manajemen Pemasaran di Indonesia: Analisis Perencanaan, Implementasi dan Pengendalian. Jilid Kedua. Jakarta: Penerbit Salemba Empat.

Lovelock, Christopher dan Wirtz, Jochen. 2007. Service Marketing: People, technology, Strategy. Singapore: Prentice Hall.

Rangkuti, Freddy. 2000. Riset Pemasaran. Jakarta: Gramedia Pustaka Utama.

2002. Measuring Customer Satisfaction: Teknik Mengukur dan Strategi Meningkatkan Kepuasan Pelanggan Plus Analisis Kasus PLNJ.Jakarta: Gramedia Pustaka Utama. 
Balance Vol. XV No. 1 | Januari 2018

Sekaran, Uma. 1992. Research Methods for Business: A Skill-Building Approach. Secon Edition. New York:John Wiley \& Son Inc.

Subramaniam, Archana, et. All. 2014. Effect of Brand Loyalty, Image and Quality on Brand Equity: A Study among Bank Islam Consumers in Kelantan, Malaysia. Asian Social Science. Volume 10. (14).

Tjiptono, Fandy. 2002.Strategi Pemasaran, Pemasaran Jasa.Malang:Bayumedia Publishing.

Umar, Husein. 2005. Metode Penelitian. Jakarta: Salemba Empat.

Umar, Husein. 2010. Riset Pemasaran \& Perilaku Konsumen. Jakarta: Gramedia.

Undang-Undang No.21 Tahun 2008 Tentang Perbankan Syariah

www.ojk.go.id. Diakses 03 Maret 2017 pukul 19.00.
Yopi. Proposal penelitian. (online). (http://yopipazzo.blogspot.co.id/2013/01/ proposal-penelitian.html). Diakses tgl. 02 Maret 2017 pukul 17.50 .

Yuliaty, Tetty. 2014. Pengaruh Kualitas Layanan Internet Banking Dan Brand Equity Terhadap Kepuasan Nasabah Pada PT. Bank Syariah Mandiri KCP Medan Aksara. Jurnal Manajemen dan Bisnis. Volume 14. (02). 120-126.

Zeithaml, L. Valerie A., Parasuraman, A., Berry, Leonardo L. 1988.Servqual; A Multiple Item Scale for Measuring Consumer Perception of Service Quality. Journal and Retailing, Vol. 64, Spring, pg. $12-40$. 